Published in "Molecular Phylogenetics and Evolution 92: 255-265, 2015"

which should be cited to refer to this work.

\title{
Diversification of the cold-adapted butterfly genus Oeneis related to Holarctic biogeography and climatic niche shifts is
}

\author{
I. Kleckova $^{\mathrm{a}, \mathrm{b}, *}$, M. Cesanek $^{\mathrm{c}}$, Z. Fric $^{\mathrm{a}, \mathrm{b}}$, L. Pellissier ${ }^{\mathrm{d}, \mathrm{e}, \mathrm{f}}$ \\ ${ }^{a}$ Faculty of Science, University of South Bohemia, Branišovská 31, 37005 České Budějovice, Czech Republic \\ ${ }^{\mathrm{b}}$ Institute of Entomology, Biology Centre of the Czech Academy of Sciences, Branišovská 31, 37005 České Budějovice, Czech Republic

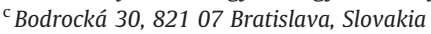 \\ ${ }^{\mathrm{d}}$ University of Fribourg, Department of Biology, Ecology E' Evolution, Chemin du Musée 10, 1700 Fribourg, Switzerland \\ ${ }^{\mathrm{e}}$ Landscape Ecology, Institute of Terrestrial Ecosystems, ETH Zürich, Zürich, Switzerland \\ ${ }^{\mathrm{f}}$ Swiss Federal Research Institute WSL, 8903 Birmensdorf, Switzerland
}

Both geographical and ecological speciation interact during the evolution of a clade, but the relative contribution of these processes is rarely assessed for cold-dwelling biota. Here, we investigate the role of biogeography and the evolution of ecological traits on the diversification of the Holarctic arcto-alpine butterfly genus Oeneis (Lepidoptera: Satyrinae). We reconstructed the molecular phylogeny of the genus based on one mitochondrial (COI) and three nuclear (GAPDH, RpS5, wingless) genes. We inferred the biogeographical scenario and the ancestral state reconstructions of climatic and habitat requirements. Within the genus, we detected five main species groups corresponding to the taxonomic division and further paraphyletic position of Neominois (syn. n.). Next, we transferred O. aktashi from the hora to the polixenes species group on the bases of molecular relationships. We found that the genus originated in the dry grasslands of the mountains of Central Asia and dispersed over the Beringian Land Bridges to North America several times independently. Holarctic mountains, in particular the Asian Altai Mts. and Sayan Mts., host the oldest lineages and most of the species diversity. Arctic species are more recent, with Pliocene or Pleistocene origin. We detected a strong phylogenetic signal for the climatic niche, where one lineage diversified towards colder conditions. Altogether, our results indicate that both dispersal across geographical areas and occupation of distinct climatic niches promoted the diversification of the Oeneis genus.

\section{Introduction}

Although allopatric and ecological speciation processes interact in evolution (Rundell and Price, 2009; Bennett and O'Grady, 2012), they are rarely studied together, especially in older radiations (cf. Vila et al., 2011; Condamine et al., 2012; Bentley et al., 2014). A clade is rarely the pure product of allopatry (Muller and Beharegaray, 2010; Imada et al., 2011). Geographical speciation can be coupled with ecological speciation (Hall, 2005; Willmott et al., 2001; Matos-Maravi et al., 2013) involving the differentiation of species lineages by changes in habitat use or behaviour (Jiggins, 2008; Chamberlain et al., 2009). Diversification along climatic gradients, such as moisture (Rieseberg et al., 1999; Gee, 2004) or

\footnotetext{
This paper was edited by the Associate Editor Francesco Frati.

* Corresponding author at: Institute of Entomology, Biology Centre of the Czech Academy of Sciences, Branišovská 31, 37005 České Budějovice, Czech Republic.

E-mail address: irena.slamova@gmail.com (I. Kleckova).
}

temperature (Keller and Seehausen, 2012) has been documented in several clades. However, the signal of ecological speciation might be blurred by non-adaptive ecological speciation (Rundell and Price, 2009). In that case, speciation via geographic isolation precedes significant ecological diversification and reproductive isolation (Swensson, 2012). Geographical and ecological speciation processes probably frequently interacted in rugged environments with unstable climates such as in the Holarctic region, especially in the diversification of cold-dwelling biota inhabiting mountains.

Distributions of Holarctic organisms were shaped by climatic changes during the past 15 million years (Vila et al., 2011), the effect of which interacted with regional topographies (Todisco et al., 2012). Cold periods interconnected biota across the Holarctic by promoting lowland dispersal events (Schmitt and Haubrich, 2008; Todisco et al., 2012) and movements of Arctic assemblages to southern latitudes (Päckert et al., 2012; Eidesen et al., 2013) followed by in-situ speciation (Vila et al., 2011). This connectivity was probably associated to species' ecological 
preferences (Vila et al., 2011). For instance, dry-adapted alpine species widely dispersed to lowlands (Schmitt and Hewitt, 2004), which had mainly an arid character, whereas alpine species not tolerant of dryness were restricted to more humid areas (e.g. along rivers) around the glaciated high mountain systems (Schmitt et al., 2006). The interactions of ecological preferences and geographical speciation processes in montane and Arctic regions are relatively well studied (Todisco et al., 2012; Eidesen et al., 2013; Yannic et al., 2014), but mainly using plants and birds as models (e.g. Drovetski, 2003; Kadereit and Baldwin, 2012; Fjeldsa, 2013). The understanding of the speciation in cold-dwelling butterflies is still limited (Kodandaramaiah and Wahlberg, 2009; Simonsen et al., 2010; Todisco et al., 2012).

Butterflies represent a model group of organisms to study the mechanisms of speciation in relation to their ecology and geographic distribution. Butterflies show conservatism in their habitat affiliations (van Swaay et al., 2006) and thermal niches (cf. Vila et al., 2011; Kleckova et al., 2014), but this remains to be tested in the evolution of cold-adapted butterfly lineages. The butterfly genus Oeneis, Hübner, 1819 (Lepidoptera: Satyrinae) arose in the Miocene (Peña et al., 2011) and diversified into 30 species across the mountains and Arctic of the Holarctic region. Here, we investigated the Holarctic diversification of this cold-dwelling genus in relation to shifts in ecological traits and geographic range. We reconstructed the biogeographic history and evolution of habitat affiliations as well as climatic requirements as drivers of diversification. Specifically, we asked: (1) Where was the origin of the distribution and radiation of this genus? (2) What are the relative contributions of geographical and ecological speciation in the evolution of the genus Oeneis? (3) Is a traditional taxonomical division of the genus Oeneis and classification of closely related genera consistent with molecular phylogeny?

\section{Methods}

\subsection{Study organisms and molecular dato}

We studied the phylogenetic relationships within the genera Oeneis, Paroeneis Moore, 1893 and Neominois Scudder, 1875 (Lepidoptera: Satyrinae, Satyrina). More than half of the Oeneis species occur in the mountainous areas of Central Asia, five species are distributed in Arctic Eurasia and roughly ten species in the Arctic and mountain regions of North America (Tuzov et al., 1997; Layberry et al., 1998; Gorbunov, 2001). Seven species are distributed in both Eurasia and North America (Tuzov et al., 1997, Table S1). Individual Oeneis species occur in steppic or alpine grasslands, tundra, taiga, mountain woodlands and screes (Tuzov et al., 1997; Layberry et al., 1998; Gorbunov, 2001). Larvae feed on various grasses (Layberry et al., 1998), hence diversification should be primarily driven by other factors than host plant shifts (cf. Schweiger et al., 2008). A phylogeny of the genus has been lacking to understand the drivers of diversification and solve the currently problematic taxonomy of the genus (Pelham, unpublished). The representatives of the genus Oeneis were traditionally sorted into two subgenera, Protoeneis Gorbunov, 2001 and Oeneis Hübner, [1819] s. str., and then to morphologically defined species groups (Table S1, Lukhtanov and Lukhtanov, 1994a; Gorbunov, 2001; Pelham, unpublished), but the internal taxonomy of the genus has not been established and differs between publications (Tuzov et al., 1997; Layberry et al., 1998; Gorbunov, 2001).

The genera Paroeneis and Neominois share similar appearance, ecology and bionomy as the genus Oeneis. The genus Paroeneis includes about six species, all inhabiting the mountains of Central Asia (Gorbunov, 2001). The genus Neominois includes 2-3 species living in the sparsely vegetated grasslands of North America, from southern Alberta to northern Mexico (Warren et al., 2008).

For our study, we used 19 species (43 specimens), representing all recognised species groups of the genus Oeneis (Gorbunov, 2001, Table S2), plus Paroeneis palaearcticus (Staudinger, 1889), P. pumilus (C. \& R. Felder, [1867]) and two (sub)species of the Neominois ridingsii ridingsii (Edwards, 1865) and Neominois ridingsii wyomingo (Scott, 1998), frequently considered as distinct species (Opler and Wright, 1999). We were able to extract DNA from 14 species, represented by at least two specimens from different populations; 9 species were represented only by 1 specimen. As outgroup taxa, we used the related Satyrinae butterflies Melanargia galathea (Linnaeus, 1758), Hipparchia statilinus (Hufnagel, 1766), Karanasa pamira (Staudinger, 1887), and Karanasa bolorica (Grum-Grshimailo, 1888).

DNA was extracted from two legs or part of the thorax of dry specimens using DNEasy extraction kit (QIAGEN). DNA was amplified by Polymerase Chain Reactions (PCR) for one mitochondrial (COI - $1487 \mathrm{bp}$ ) and three nuclear genes (GAPDH - $691 \mathrm{bp}, \mathrm{RpS5}$ - $617 \mathrm{bp}$, wingless - $400 \mathrm{bp}$ ), using forward-reverse primer pairs described in Wahlberg and Wheat (2008). In total, the genetic information contained 3207 bp. For COI synthesis, we used two primer pairs, LCO-HCO for the first half and Jerry-Pat for the second half, for GAPDH primer pair Frigga-Burre, for RpS5 pair rpS5degFrpS5degR and for wingless LepWG1-LepWG2. PCR run in $20 \mu \mathrm{l} \mathrm{vol-}$ ume by using PPP mastermix (TOP-BIO, following a standard protocol). PCR thermal program $95^{\circ} \mathrm{C}$ for $5 \mathrm{~min}, 40$ cycles at $94{ }^{\circ} \mathrm{C}$ for $30 \mathrm{~s}$, annealing temperature $50{ }^{\circ} \mathrm{C}$ for $30 \mathrm{~s}$ (COI, wingless) resp. $55^{\circ} \mathrm{C}$ for $30 \mathrm{~s}$ (GAPDH, RpS5), $72{ }^{\circ} \mathrm{C}$ for $1 \mathrm{~min} 30 \mathrm{~s}$ and final extension period at $72{ }^{\circ} \mathrm{C}$ for $10 \mathrm{~min}$. The amplified genes were sequenced commercially by the Macrogen Company (dna.macrogen.com) using an ABI 3730XL DNA analyser. Sequences were aligned manually in the program BIOEDIT v 7.0.5.3 (Hall, 1999). Sequences of outgroup taxa as well as of Neominois r. ridingsii were downloaded from GenBank (Peña et al., 2011, http://www.ncbi. nlm.nih.gov/, Table S2).

\subsection{Phylogenetic analyses}

Maximum parsimony analysis was performed in software TNT 1.1 (Goloboff et al., 2008) using Melanargia galathea as outgroup. All characters (with gaps as the fifth state) were treated as unordered and equally weighted. We performed heuristic searches, using the New Technology Search algorithms with a level of search 15 , followed by branch swapping of resulting trees. The strict consensus tree was built from 10 final trees.

Two Bayesian analyses were performed using MrBayes v 3.1.2 (Ronquist and Huelsenbeck, 2003) and Beast v 1.8.0 (Drummond and Rambaut, 2007) with Melanargia galathea as outgroup. First, we performed the model tests of substitution rates. The best fit of the model of evolution was determined by using the FindModel tool of the Los Alamos HIV databases and compendia (www.hiv.lanl.gov), which implements Modeltest script (Posada and Crandall, 2001) calculating AIC scores, and the program Weighbor (Bruno et al., 2000) generating the tree based on Jukes-Cantor distances.

In the MrBayes analysis, we defined variable evolution rates, which were independent for each partition, representing one gene. The most general GTR+G substitution model was applied to all partitions. Markov Chain Monte Carlo Metropolis-Hastings (MCMC) algorithm with 4 chains was run for 10 million generations. Chains were sampled every 1000 generations. The convergence of two runs was checked visually according to the log likelihood of both runs. The first 2 million trees were discarded as burn-in. 
BEAST analysis with relaxed uncorrelated lognormal clock model and speciation by Yule process was used to estimate the timing of diversification events within the genus Oeneis. We used two secondary calibration points, based on divergence time estimates of the tribe Satyrini (Peña et al., 2011), which used fossils for calibration. We defined the monophyly and age of MRCA of $13( \pm 4)$ Ma for the taxa set which included all representatives of the genera Oeneis (including Neominois) + Karanasa. The second calibration point was set to the timing of the split between Neominois sp. and 0 . jutta with an age of MRCA 9 Ma $( \pm 4)$. Gene evolutions were estimated by using separate partitions for each gene with site model GTR+G for COI, TN93+G for GAPDH, and finally $\mathrm{HKY}+\mathrm{G}$ for RpS5 and wingless. For wingless and RpS5, simpler models than suggested by the model tests were used to avoid overparameterisation and to reach diagnostics of Effective Sample Size (ESS) $>200$ of traces of MCMC in Tracer v 1.5.0 (Rambaut and Drummond, 2003-2009). We specified MCMC chain length of 30 million, screened every 1000 steps. Operators were auto-optimised. Parameter ucld.mean was set as lognormal, while other parameters of BEAST analysis were left in default values. The BEAST analysis was repeated with three independent runs and the trees were combined with LogCombiner v 1.8.0., with 3000 trees per run as burn-in. The final maximum clade credibility tree was checked by TreeAnnotator $\mathrm{v}$ 1.8.0, using median node heights and posterior probability limit 0 , annotating all nodes from all trees obtained by BEAST. Final trees resulting from Bayesian analyses were visualised using software FigTree v 1.3.1 (Rambaut, 2009). We ran the analysis using the computational facilities of MetaCentrum of the Czech National Grid Infrastructure (https://metavo.metacentrum.cz/) and CIPRES (Miller et al., 2010).

\subsection{Biogeography and ancestral habitats reconstruction}

We pruned the final Beast tree in the APE package (Paradis et al., 2004) of the software R v 2.15.2 (R Core Team, 2012) to obtain a phylogeny with only one tip per species of the genera Oeneis spp. and Neominois spp (paraphyletic). We defined four distribution areas according to centres of endemism of the genus: (A) Alps, (B) Mountains of Central Asia (including Altai, Sayan, Karakoram, Saur, Tarbagatai, Tian-Shan, Pamir, Himalayas), (C) Arctic (Eurasian taiga and tundra) and (D) North America. In addition, we classified the species habitat into four categories: (a) xerophilous, (b) mesophilous, (c) open and (d) woodland habitats from information published in Lukhtanov and Lukhtanov, 1994a; Layberry et al., 1998; Gorbunov, 2001; personal observations by MC and ZF; and for $O$. buddha by Milan Kopp.

We used RASP v 2 software (Reconstruct Ancestral State in Phylogenies; Yu et al., 2013) to reconstruct the biogeography and ancestral habitats of the genus. Biogeographical hypothesis and ancestral habitat reconstructions were inferred by running Bayesian Binary MCMC analysis (BBM), without specifying outgroup taxa and with maximum number of areas set equal to four for biogeographic reconstruction and two ancestral habitat reconstructions. We used estimated F81 state frequencies and the gamma among-site rate variation model. The MCMC analysis number of cycles was 50,000 with discard (burn-in) of 100 samples. We ran separate analyses for dry/wet and for open/woodland habitat traits.

\subsection{Evolution of climatic and habitat requirements}

For each species, we collected occurrences data from the literature and biodiversity databases (Appendix A). We recovered extensive occurrences for most species, except for $O$. buddha, $O$. fulla, $O$. mongolica and $O$. mulla, occurring in remote areas, and for N. wyomingo, the rare North American species $\quad(<10$ occurrences). We extracted climatic information from Worldclim climate layers (http://www.worldclim.org/, Hijmans et al., 2005, ESRI grid, resolution $10 \times 10 \mathrm{~km}$ ) in R package Raster (Hijmans et al., 2014) for the distribution points. For each species and each climatic variable, we computed the average value. We investigated annual mean temperature (bio1), maximum temperature (bio5), minimum temperature (bio6), temperature seasonality (bio4), annual precipitation (bio12) and precipitation seasonality (bio15), given that butterflies of the genus show preferences along temperature and moisture gradients.

The presence of phylogenetic signal in habitat and climatic requirements was tested using Blomberg's $K$ statistics (Blomberg et al., 2003), implemented in the package Picante (Kembel et al., 2010 ) in R. $K$-value closer to 1 corresponds to a Brownian motion process, which implies some degree of phylogenetic signal indicating trait structuring across the phylogeny. The presence of phylogenetic signal was tested also for the reduced dataset, which excluded species with low numbers of distribution points. Climatic variables whose evolution was non-random ( $K$-values close to 1) were mapped as continuous traits on the pruned tree using the R package phytools (Revell, 2012).

\section{Results}

\subsection{Models tests}

The General Time Reversible substitution model with Gamma distribution of rate variation among sites $(G T R+G)$ was identified to be the best model for $\mathrm{COI}$ and RpS5, and the Tamura-Nei substitution model with Gamma distribution ( $\operatorname{TrN}+\mathrm{G}$ ) for GAPDH and wingless. The most general GTR $+G$ substitution model was applied to all partitions. For MrBayes analysis, the TrN model suggested to be used for GAPDH (AIC value 3021.96) and wingless (AIC value 1044.99) was not implemented. We used GTR+G, which was the second best model of evolution (AIC values 3026.78 and 1047.45, respectively for GAPDH and wingless).

\subsection{Phylogenetic relationships}

The trees obtained from the maximum parsimony analysis (Fig. S1), the Beast analysis (Fig. 1) and the MrBayes analysis (Fig. S2) differed in detection of relationships among members of the subgenus Protoeneis (Table S1) and among O. glacialis, 0 . fulla and $O$. norna. The maximum parsimony resulted in polytomies among O. sculda, O. tarpeia and (O.uhleri, (O. diluta, O. mongolica)) and among O. fulla, O. glacialis and O. norna (Fig. S1). In MrBayes, O. sculda was basal to the O. tarpeia and (O.uhleri, (O. diluta, O. mongolica)) (Fig. S2). In contrast, in the Beast analysis, O. tarpeia was basal to the 0 . sculda and the remaining three species (Fig. 1). Both Bayesian inference analyses showed basal position of 0 . glacialis in relation to ( $O$. fulla, $O$. norna). Phylogenetic reconstructions detected ambiguous relationships among 0 . tarpeia - O. lederi and 0 . jutta - O. magna. The maximum parsimony, the Beast analysis and the MrBayes analysis consistently indicated monophyly of $O$. tarpeia and $O$. lederi. $O$. jutta and $O$. magna were monophyletic according to the maximum parsimony and MrBayes analysis. According to the Beast analysis, O. magna was basal to O. jutta.

The relationships among groups were congruent across all analyses (Figs. 1, S1, and S2). The subgenus Protoeneis was found to be basal to the Neominois spp. and the subgenus Oeneis. The genus Neominois was in all analyses placed inside the genus Oeneis and it was a sister taxon to the subgenus Oeneis, which included representatives of the bore, the buddha, the hora and the polixenes groups (Table S1, Fig. 1). Therefore the traditionally recognised genus Oeneis is paraphyletic. Our molecular study showed that 


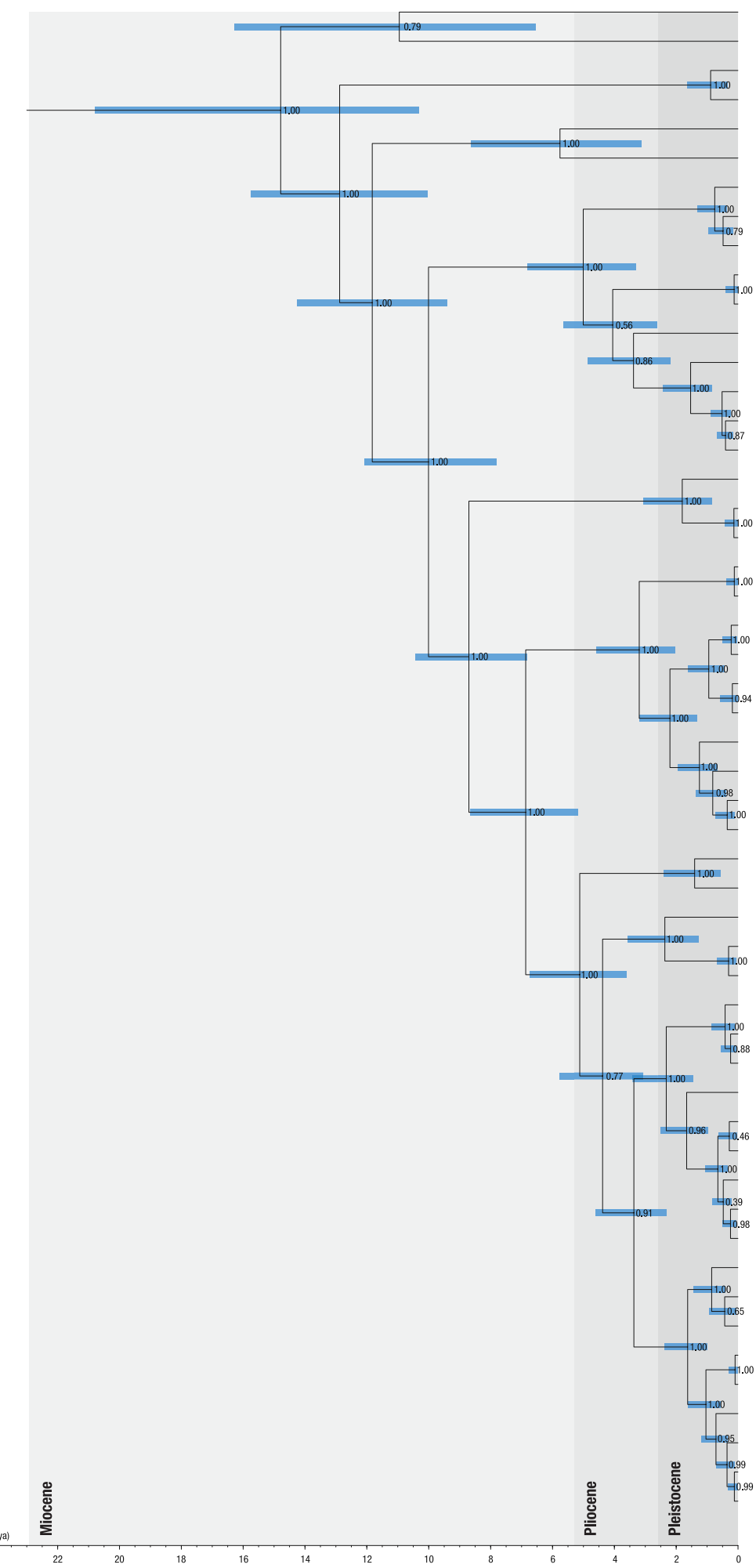

Hipparchia statilinus (HufnaGe, 1766) EW25-24

Melanargia galathea (LINNAEUs, 1758) EW24-17

Paroeneis pumilus (C. \& R. FeldER, [1867]) CB12-1

Paroeneis palaearcticus (STAUdinger, 1889)

Karanasa pamira (STAudNGER, 1887) CP-AC23-32

Karanasa bolorica (Grum-GrSHMALL, 1888) NW166-10

Oeneis tarpeia (PALAS, 1771) AB7-6

(PALAS, 1771) OE-65B

Protoeneis

Oeneis lederi ALPHERAKY, 1897 OE-72B

tarpeia sp. group

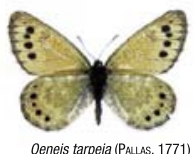

Oeis sculda(EVERSMANN, 1851) CB12-19

Oeneis sculda (Eversmann, 1851) OE-33

Oeneis uhleri HÜ̈NER, [1819] OE-52

Oeneis diluta LukHTAnov, 1994 OE-35

Oeneis mongolica (ОвеRтHÜR, 1876) CB10-5

Oeneis mongolica (OВеRTHÜR, 1876) CB10-3

Oeneis mongolica (OВERTHÜR. 1876) CB10

Oeneis ridingsii (EDWARDs, 1865) CD-1-1

Deneis wyomingo (Scort, 1998) AB10-15

Oeneis wyomingo (Scort, 1998) AB10-14 tarpeiasp. group

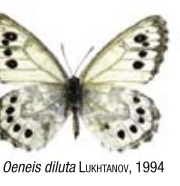
Deneis ammon ELWES, 1899 OE-13

Oeneis ammon ELwEs, 1899 OE-12

Oeneis chryxus (E. DoublEDAY, [1849]) OE-03

Oeneis chryxus (E. DoublEDAY, [1849]) OE-01

Oeneis chryxus (E. Doubleday, [1849]) OE-02

Oeneis chryxus (E. DoublEDAY, [1849]) OE-05

Oeneis bore (SCHNEDER, 1792) OE-07

Oeneis bore (SCHNEIDER, 1792) ZF-LY-000536

Oeneis bore (SCHNEIDER, 1792) OE-27

Oeneis bore (SCHNEDER, 1792) CB12-3

Oeneis buddha Grum-GrSHIMALLo, 1891 CB12-5

Oeneis buddha Grum-Grshimallo, 1891 CB12-6

Oeneis mulla Staudinger, 1881 OE-54

Oeneis elwesi Staudinger, 1901 OE-46

Oeneis elwesi Staudinger, 1901 OE-71B

Oeneis glacialis (MoL, 1783) 0E-48

Oeneis glacialis (MoL, 1783) OE-49

Oeneis glacialis (MoL, 1783) OE-50

Oeneis fulla (EversMann, 1851) OE-55

Oeneis norna (THUNEERG, 1791) OE-10

Oeneis norna (THUNBERG, 1791) CB 12-16

Oeneis norna (THUNBERG, 1791) OE-74B

Oeneis norna (THUnBERG, 1791) OE-18

Oeneis norna (THunBerg, 1791) CB12-18

Oeneis magna Graeser, 1888 CB12-17

Oeneis jutta (HÜвNER, 1806) EW4-1

Oeneis jutta (Hüвner, 1806) ZF-LY-001442

Oeneis aktashi LukHTAnov, 1984 OE-69B

Oeneis aktashi LuKHTANov, 1984 OE-16

Oeneis melissa (Fabriclus, 1775) OE-53B

Oeneis melissa (FABrlcius, 1775) OE-29

Oeneis melissa (FABRicius, 1775) 0E-04

Oeneis melissa (FABRICUS, 1775) OE-23

Fig. 1. Phylogenetic tree and time estimates of diversification occasions (Mya) of the butterfly genus Oeneis resulting from Bayesian inference by Beast. The numbers are the posterior probabilities of the respective nodes.

Neominois represents a monophyletic lineage within the genus Oeneis. The Neominois diverged from Asian representatives of the genus Oeneis by vicariance. The generic name Neominois should therefore become a subgeneric level (stat. nov.) and put the name Neominois (syn. n.) as a synonymum to the name Oeneis on the generic level. The bore group was basal, while the buddha group was sister to (the hora + the polixenes) groups. In addition, O. aktashi, which was traditionally considered to be related to $O$. mulla and $O$. elwesi of the hora group, was more related to 0 . melissa of the polixenes species group in all analyses. 


\subsection{Timing of diversification events}

The origin of the genus at Miocene (around $13 \mathrm{Ma}$ ) was followed by diversification of the three main subgenera. The Beast analysis estimated the age of the subgenus Protoeneis around $12 \mathrm{Ma}$. The remaining two subgenera Neominois and Oeneis split around $10 \mathrm{Ma}$. Most of current lineages appeared during the Pliocene (5-2.5 Ma). The Pleistocene period (2.5 Ma - now) induced the main diversification on the species and sub-species levels.

\subsection{Biogeography and ancestral habitats reconstruction}

The origin of the genus Oeneis was located in the mountains of Central Asia (region B) (node 41, Fig. 2 and Table S5). According to the biogeographic reconstruction, the genus colonised North America (region D) via Beringian land bridges several times during the Miocene, Pliocene and Pleistocene. In particular, the Miocene vicariant event (ca $9 \mathrm{Ma}$, node 35) led to the separation of Neominois spp., which now inhabit the Rocky Mountains of North America. Pliocene or early Pleistocene vicariant event (ca $3 \mathrm{Ma}$ ) led to the origin of North American O. uhleri (node 38), distributed from Alaska to New Mexico and, likely of the common ancestor of 0 . chryxus and 0 . bore (nodes 32,31 ). The Pleistocene dispersions to America may have occurred in a common ancestor of 0 . jutta, O. magna, O. aktashi and O. melissa (node 26, low probability) or, with higher probabilities, simultaneously with the splitting of the sister species pairs, O. jutta from O. magna (node 24) and O. aktashi from 0 . melissa (node 25). The Arctic (region C) was probably colonised by 0 . bore during the Pliocene/early Pleistocene (node 31). The arctic distribution of $O$. jutta, O. magna, O. melissa and O. norna could originate from a unique Pliocene event (node 27, low probability) or from several independent dispersal events across the Pleistocene (nodes 22, 23, 24, 25, 26). The Alps (region A) with only one species, $O$. glacialis, were colonised during the Pliocene/early Pleistocene (node 23).

The RASP analyses of habitat affiliations showed that the ancestral habitats of the genus were xerophilous grasslands (node 41, Figs. S3 and S4). The species of the subgenus Protoeneis and subgenus Neominois were conservative in their preference of dry habitats (Table S6 and Fig. S3). The shift to wet habitats probably appeared in a common ancestor of the bore, the buddha and the polixenes group (node 33) during the Miocene, or, with lower probabilities, later within the bore (nodes 32,31 ), the buddha (node 30) and the polixenes (nodes 29, 27, 22, 26 and 24) groups. Woodlands were colonised at least two times independently by representatives of the subgenus Protoeneis (nodes 40,39) during the late Miocene or during the Pliocene and next, during the Pliocene or Pleistocene, by the polixenes group of the subgenus Oeneis (nodes 22, 23, 24, 26 and 27) (Table S7 and Fig. S4).

\subsection{Evolution of climatic and habitat requirements}

The strongest phylogenetic signal was expressed in the requirements of maximal temperature (Table S3). Basal members of the subgenus Protoeneis and also subgenus Neominois occur in regions with higher maximum temperature then ancestors and members of the subgenus Oeneis (Fig. 3). The analyses performed on the reduced dataset, excluding species with low numbers of occurrences, provided congruent results (Table S4). Possible differences in climatic preferences in the subgenus Protoeneis, the subgenus Oeneis and subgenus Neominois were illustrated by Principal Component Analysis (PCA) and duality diagrams (dudi) implemented in R package ade4 (Dray et al., 2007), in relation to the available climatic environment of Northern Hemisphere. Oeneis species occupied climatic space with low temperatures (on the first axes of climatic PCA), and with higher precipitations (on the second axes) within the Northern Hemisphere (Fig. 4). The species of the subgenus Protoeneis and subgenus Neominois occurred in slightly warmer and dryer environments with higher precipitation seasonality compare to the subgenus Oeneis.

\section{Discussion}

\subsection{Biogeography}

The early Oeneis diversification within the ancestral region of the mountains of Central Asia (region B) dates back to the Miocene and the Pliocene (Fig. 2), contemporary to the uplift of the Himalayas and adjacent ranges (Valdiya, 2002; De Grave et al., 2007). The uplift promoted the speciation of mountain birds (Fjeldsa et al., 2012; Drovetski et al., 2013), plants (Xu et al., 2010), but also cold-adapted butterflies (Kodandaramaiah and Wahlberg, 2009; Leneveu et al., 2009). Our dating suggests that the early speciation of Oeneis provides another example of diversification associated with the Himalayan uplift.

Later speciation events in the genus were largely associated to dispersal events from the Palaearctic to Nearctic via Beringian land bridges, similarly to other Holartic butterfly genera, e.g. Boloria (Simonsen et al., 2010), Limenitis (Mullen, 2006) or Coenonympha (Kodandaramaiah and Wahlberg, 2009). Oeneis butterflies dispersed to North America through the second (from the Miocene to the late Pliocene, 14-3.5 Ma) and the third (the Pleistocene, 1.5-1 Ma) Beringian Land Bridge (Sanmartin et al., 2001). After the submersion of the second Beringian Land Bridge, isolation likely led to the origin of subgenus Neominois and 0 . uhleri, and probably also to the split of sister pair $O$. chryxus and $O$. bore (Figs. 2 and 5). The third Beringian Bridge connection enabled the formation of the recent Holarctic distribution of $O$. bore, $O$. melissa and O. jutta, which dispersed from Asia to North America during the Pleistocene. The biomes of the Beringian bridges provided a mosaic of diverse habitats (Elias et al., 2000). Open-habitat specialists 0 . uhleri, subgenus Neominois and 0 . chryxus dispersed cross the taiga-prevailing (Sanmartin et al., 2001) second Beringian Bridge, and woodland species O. bore and O. jutta were able to spread cross the tundra-prevailing third Beringian Bridge (Sanmartin et al., 2001).

The Arctic region was colonised by the bore and the polixenes species groups at least two times independently. Ancestors of these groups probably colonised the Arctic after the climatic cooling of the Pliocene (Fig. 2, node 27, node 31), in coincidence with the emergence of this new biome (Zachos et al., 2001). Arctic species, 0 . meliss $a$ and $O$. jutta of the polixenes group, might have split from their sister species 0 . aktashi and O. magna, either in the Arctic (region C) or in the mountains of Central Asia (region B, nodes 24 and 25). The last Arctic species included in our study, O. norna, has a sister relationship to $O$. fulla, which inhabits the mountains of Central Asia (region B). Thus, O. norna probably colonised the Arctic from the Asian part of the Palaearctic. Basal to the sister pair $O$. norna and $O$. fulla was the only species of the European Alps, $O$. glacialis. The basal position of $O$. glacialis could be a consequence of large scale Pliocene/early Pleistocene colonisation. This colonisation could be followed by Pleistocene extinctions of their common ancestor after a warming event, hypothetically occurring in the centre of the Palaearctic as observed in e.g. Coenonympha butterflies (Kodandaramaiah and Wahlberg, 2009). Together, our results suggest that cold-climate phases opened dispersal routes from 


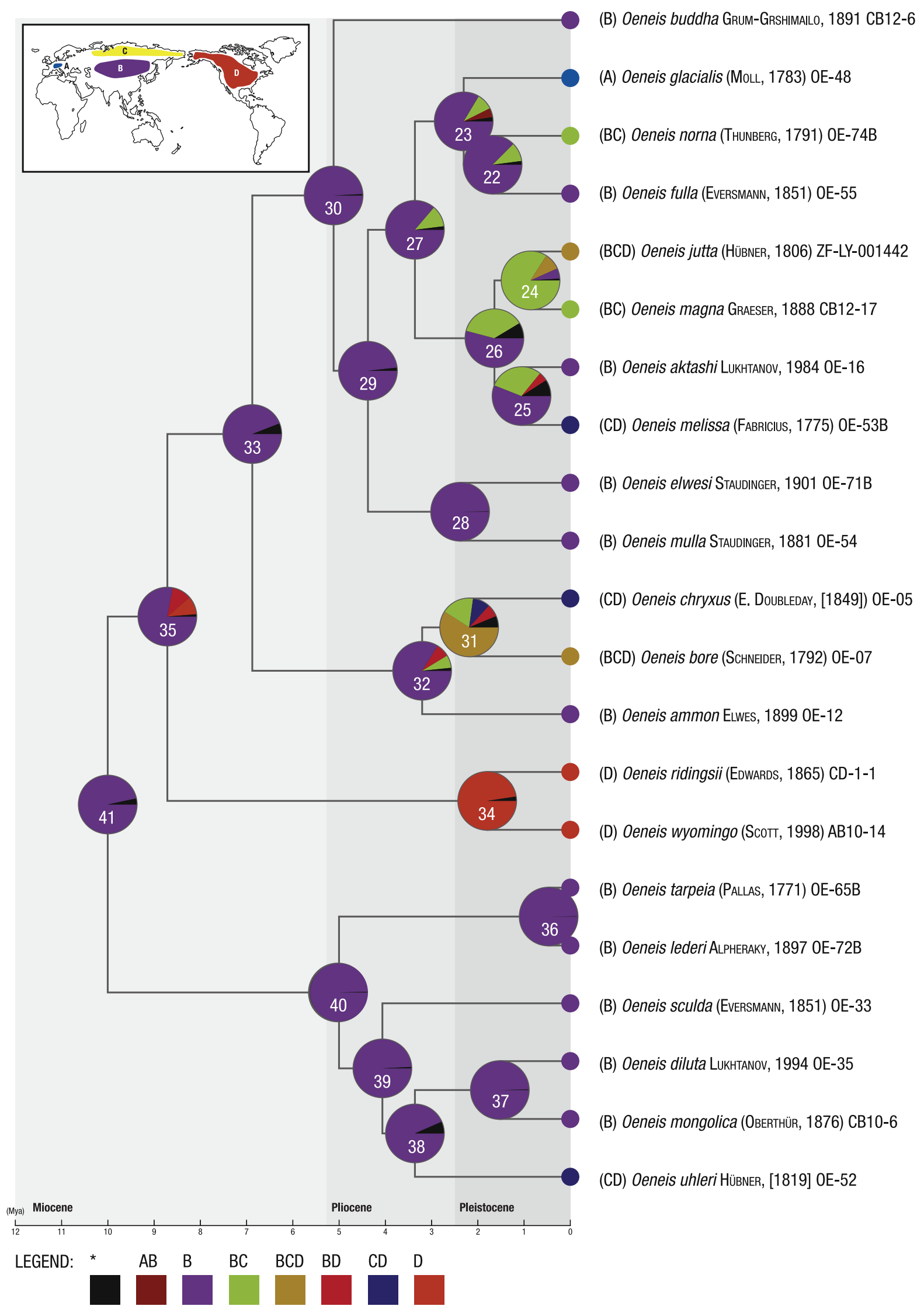

Fig. 2. Historical biogeography of Oeneis butterflies. RASP reconstruction of ancestral distributions of Oeneis butterflies based on the phylogenetic tree resulting from Beast analysis. Pie charts on each node depict the relative probabilities of ancestral ranges; A: European Alps, B: Mountains of Central Asia, C: Arctic, D: North America. 


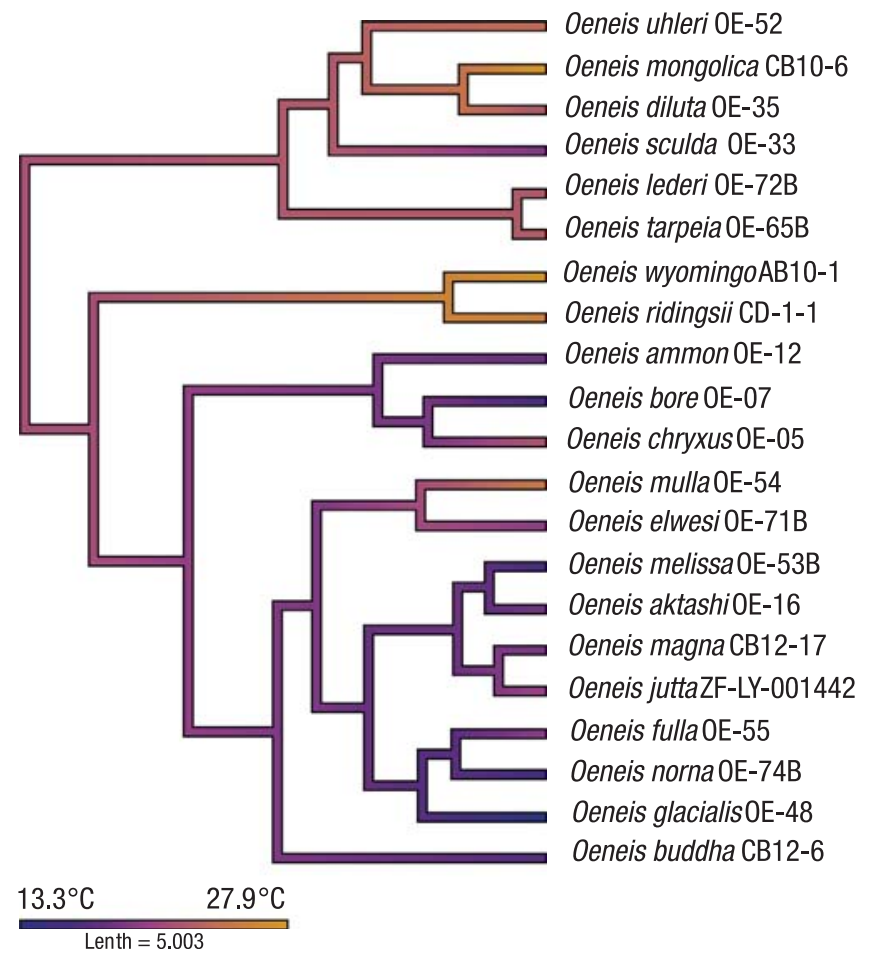

Fig. 3. Ancestral climate reconstruction for maximum yearly temperature (bio5), which displayed strong phylogenetic signal within the arcto-alpine butterfly genus Oeneis. Branch colours indicate values of the bio5 (see legend). mountain areas and enabled colonisation of North America, the Arctic and the Alps.

\subsection{Refuges for cold-dwelling biota}

The mountain areas of the Holarctic had a crucial importance for promoting and maintaining a large diversity of species within the Oeneis genus. The mountains of Central Asia were free of ice since the Miocene (Kamelin, 1998; Sanmartin et al., 2001) and represented general long term refugia of temperate biota (Tiffney 1985; Chytry et al., 2012; Condamine et al., 2012). The oldest Oeneis lineages (members of the subgenus Protoeneis) and two-thirds of Oeneis diversity (19 species, Table S1) occur in the mountains of Central Asia (region B). In particular, the majority of the diversity occurs in the Altai Mts. and Sayan Mts., with 13 species (O. aktashi, O. ammon, O. brunhilda, O. diluta, O. elwesi, O. fulla, O. lederi, O. magna, O. nanna, O. sculda, O. tarpeia, O. urda; Database of Animals of the Altai-Sayan Ecoregion). The Altai Mts. and Sayan Mts. are characterised by a diversity of habitat (Kamelin, 1998), with southern slopes covered by steppe and northern slopes by mixed woodlands (Kamelin, 1998; Chytry et al., 2012). Pleistocene persistence of habitat diversity might have ensured the close vicinity of diverse habitats and thermal environments, and facilitated species survival under climatic changes. Similarly, the North American Rocky Mountains served as climatic refugium (Weber, 2003; de Chaine and Martin, 2005), for two old evolutionary lineages (Neominois spp., 0 . uhleri) and seven younger species (O. alberta, O. nevadensis, O. macouni, O. bore, O. jutta, O. polixenes, $O$. melissa, O. chryxus). Our study confirms the general importance of mountain regions for long-term survival of

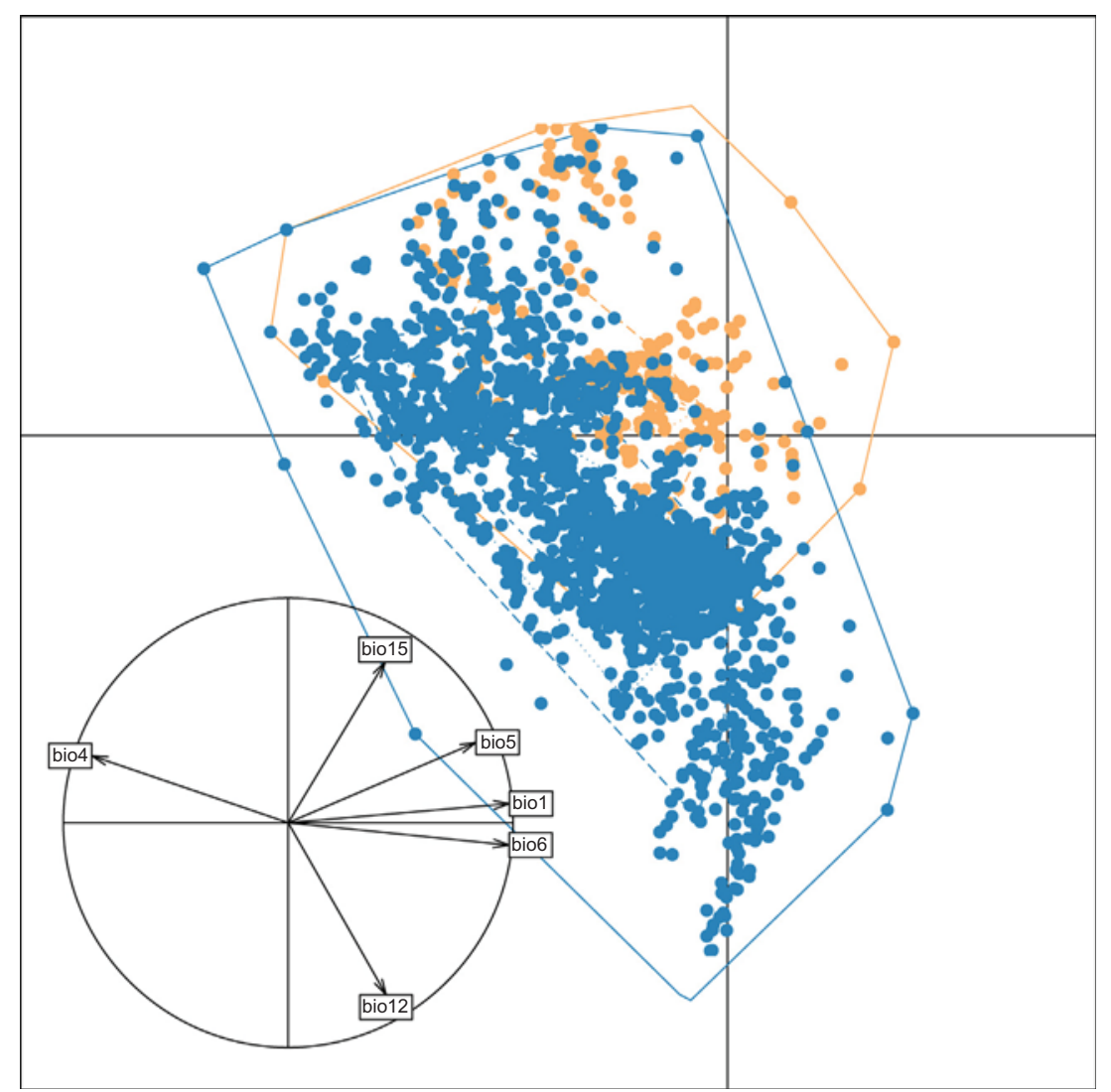

Fig. 4. Principal Component Analysis (PCA) and duality diagrams illustrate climatic space occupied by the subgenus Protoeneis and the subgenus Neominois (orange circles) and the subgenus Oeneis (blue circles within the climate available in the Northern Hemisphere. Climatic variables included in the PCA were annual mean temperature (bio1), maximum temperature (bio5), minimum temperature (bio6), temperature seasonality (bio4), annual precipitation (bio12) and precipitation seasonality (bio15). (For interpretation of the references to colour in this figure legend, the reader is referred to the web version of this article.) 


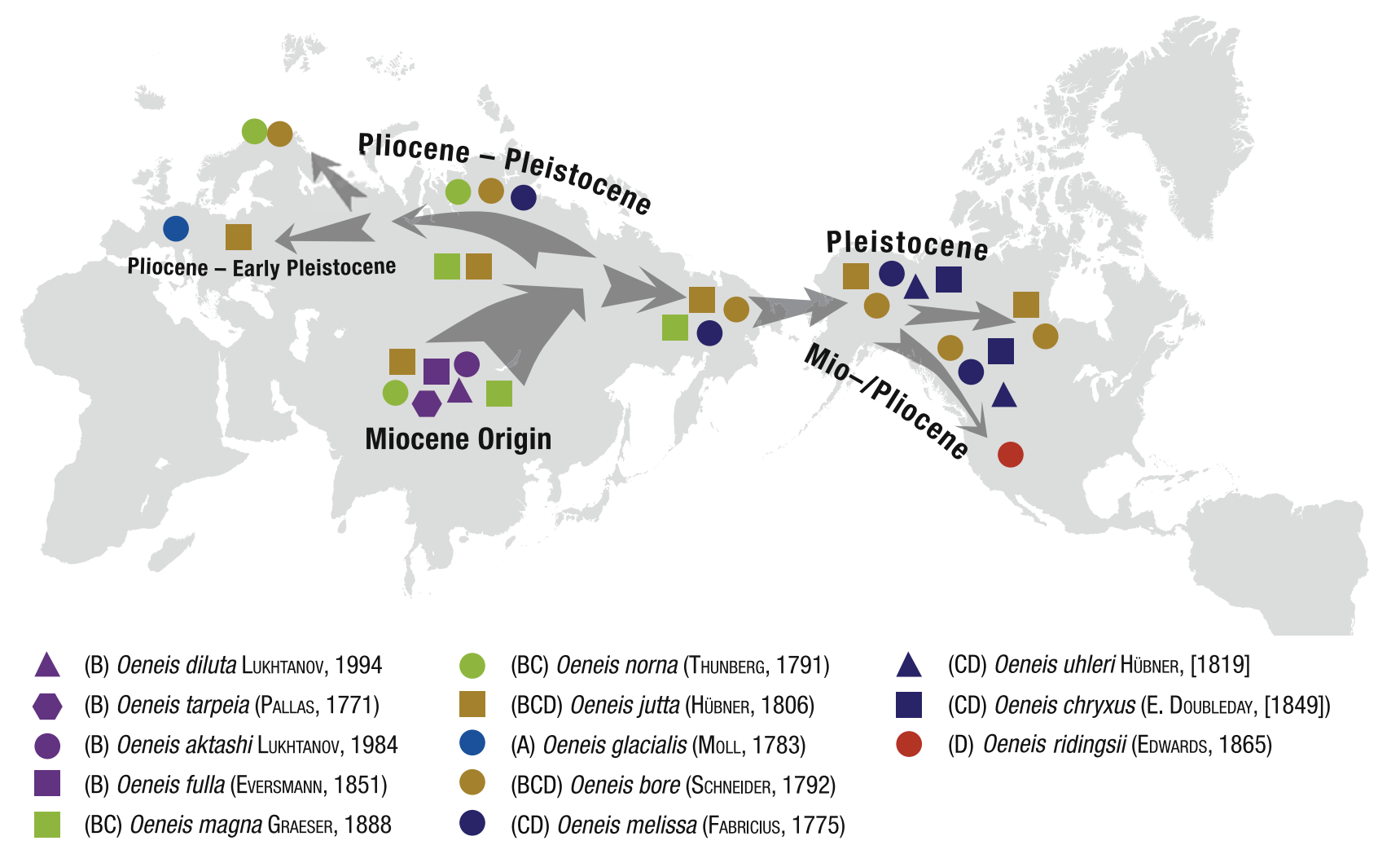

Fig. 5. The main colonisation routes of representatives of the butterfly genus Oeneis.

cold-dwelling invertebrates. Mountain regions provided a more climatically stable environment compared to the Arctic, the extreme northernmost area on Earth.

Arctic Oeneis are relatively young, with Pliocene or the Pleistocene origin, and their differentiation was probably driven by extreme fluctuations of suitable habitats. Occurrences of all Arctic Oeneis species (Region C, Table S1) within Beringia support a primary refugial importance of this area for species survival (Yannic et al., 2014). Beringia was ice-free during the whole Pleistocene and served as refugium for mammals (Hope et al., 2013), plants (Eidesen et al., 2013) and other insects (Elias et al., 2000). Beringia could also represent another speciation centre for Oeneis butterflies, analogically to small mammals, which diversified in Beringia during glacial cycles by gradual adaptation (Hope et al., 2013). Further, we do not exclude the importance of smaller refugia outside of Beringia such as Siberia (Hope et al., 2010; Eidesen et al., 2013) for survival of some species/populations during the Pleistocene. More detailed studies, including population structure (cf. Todisco et al., 2012) are needed to reveal finer biogeographic patterns.

\subsection{Ecological speciation}

Geographic speciation can interact with adaptive speciation or with non-adaptive ecological speciation (Rundell and Price, 2009). We found a phylogenetic signal in thermal niche preferences (Table S3) arising from the difference between the subgenus Protoeneis inhabiting the mountains of Central Asia with warmer conditions (Figs. 3 and 4), compared to the subgenus Oeneis with geographical range shift towards the Alps, North America and the Arctic (Fig. 2). This result suggests that shifts in the geographical range in Oeneis were accompanied with shifts in its occupied thermal niche, especially when moving towards the Arctic. Some lineages might have been pre-adapted to cold conditions which facilitated their range shifts as shown for cold adapted lineages of Polyommatus butterflies, which were better able to tolerate cold environments and use the Beringia land bridge (Vila et al., 2011). Similarly, in Oeneis, possible climatic niche-shift in direction to tolerance to lower temperatures might have facilitated dispersions of the subgenus Oeneis to new mountain ranges and Arctic areas.

\subsection{Systematic and taxonomic implications}

According to the reconstructed phylogeny, the North American Neominois spp. is placed within the Holarctic genus Oeneis (Figs. 1, S1, and S2). The Neominois spp. were hypothetised to be related to other Satyrini butterflies of genera Hipparchia, Karanasa or Oeneis (Warren et al., 2008) and the molecular phylogeny of the Satyrini butterflies placed Neominois in a sister relationship with Oeneis jutta (Peña et al., 2011). The genus Neominois was considered to be monotypic, but two other taxa were described in 1998 (Scott, 1998) and ten years later (Warren et al., 2008). Whereas our dataset does not allow us to clarify the situation of 0 . wyomingo, the combination of the recognised species names should be $O$. ridingsii (Edwards, 1865) (comb. n.) and O. carmen (A. Warren, Austin, Llorente, Luis \& Vargas, 2008) (comb. n.).

Phylogenic relationships detected by our molecular study were basically congruent with the traditional division of the genus (Table S1), with the exceptions of the traditional position of $O$. aktashi, and further, some species have an ambiguous status. o. aktashi, which was considered to be a member of the hora species group, was found to have a sister relationship to 0 . melissa from the traditional polixenes species group (Gorbunov, 2001). The ambiguous phylogenetic relationships of the closely related O. tarpeia - O. lederi and O. jutta - O. magna has to be solved by more detailed species sampling. Also, we do not exclude parapatric speciation, with gene flow among isolated subpopulations (species) limited by geographic barriers, in closely related taxa like 
O. magna/O. jutta or O. tarpeia/O. lederi. (but see Kim et al., 2013). Finally, phylogenetic relationships detected within the subgenus Protoeneis differed among computational methods: MrBayes analysis (Fig. S2) indicated that the traditional division of the subgenus into the urda and the tarpeia species groups (Table S1) is unsupported, because species of the tarpeia group were included within the urda group. Contrary, the Beast analysis (Fig. 1) supported traditional division of the subgenus Protoeneis.

\section{Conclusions}

Our study links together the phylogeny, biogeography and thermal niche divergence to assess the role of geographical and ecological speciation in cold-dwelling butterflies. The ancestral area of the genus Oeneis is located in the mountains of Central Asia and dispersions to peripheral areas promoted the diversification of the genus. The dispersal and formation of new lineages in the Arctic, Alps and North America were associated with shifts in the species habitat associations and thermal niche, suggesting adaptive or non-adaptive ecological speciation. Our study illustrates the conservatism of thermal climatic niche along lineages, which suggests that ongoing climate change will drive an upward and northward distribution of those cold-adapted butterflies. Last but not least, we have found that the Nearctic genus Neominois has to be synonymised with Oeneis, and further, we provided a molecular-based skeleton for modern taxonomy of the genus.

\section{Acknowledgements}

We are indebted to many people who provided us with Oeneis specimens from their collections (J. Benes, S. Ewert, M. Kalabza, M. Kopp, P. A. Opler, L. Spitzer, M. Zapletal, K. Zimmermann) as well as to people who provided valuable comments about the biology and taxonomy of Oeneis butterflies (P.A. Opler, J. Pelham, M. Kopp), phylogenetic analyses (P. Matos Maravi, S. Segar, O. Rican), and to M. Sweney for linguistic corrections. Two anonymous reviewers contributed valuable comments. The project was funded by the Grant Agency of the Czech Republic (P505/10/2248), and the Grant Agency of the University of South Bohemia (106/2010/P, 135/2010/P).

\section{Appendix A. Sources of Oeneis occurrence data}

\section{Databases and private collections}

Arctos (http://arctos.database.museum/taxonomy.cfm) [April 2014]

BOLD (http://www.boldsystems.org/index.php/Public_BINSearch coordinates of species in the public part of the database after search of BINs AAA3562, AAA8029, AAA2560, AAB8090, AAB9629, AAD0556, AAD0600, AAD3088, AAD3111, AAI3057, AAK3069, AAP3620, AAP4075, ABW5892, ABX6327, ABZ7577, ACE5691, ACE9580, ACF4493)

GBIF (http://www.gbif.org/) [April 2014]

Martin Cesanek Coll. (O. mongolica)

Data from GBIF were supplied by the following institutions or collections:

European Distributed Institute of Taxonomy (EDIT) 2007-2010 - All Taxa Biodiversity Inventory + Monitoring (ATBI+M) in "Parc

National du Mercantour" (France) and "Parco Naturale delle Alpi Marittime" (Italy)

Natural History Museum, University of Oslo: Arthropod collection, Tromsa, Museum

The Provincial Museum of Newfoundland and Labrador Natural History Collection

Yale Peabody Museum, (c) 2009. Specimen data records available through distributed digital resources

iNaturalist.org: iNaturalist research-grade observations

Agriculture and Agri-Food Canada, Saskatoon

The Norwegian Biodiversity Information Centre (NBIC): Norwegian Species Observation Service

New Brunswick Museum Collection

University of Alaska Museum Observation data (non-marine arthropods)

Gerald Hilchie Collection

Manitoba Museum of Man and Nature

Finnish Museum of Natural History: Finnish Entomological Database: Lepidoptera

National Museum of Natural History Luxembourg Recorder database

University of Alaska Museum Insect Collection (UAM), University of Alaska Fairbanks

Memorial University Department of Biology Collection

Natural History Museum, University of Oslo: Lepidoptera collection, Natural History Museum, University of Oslo

McMaster University Collection

Canadian Biodiversity Information Facility: Peter Hall Observations

Canadian National Collection (CNC) of Insects, Arachnids and Nematodes

University of Alberta Museums: University of Alberta Entomology Collection (UASM)

M. Gollop Collection

Biologiezentrum Linz Oberoesterreich: Biologiezentrum Linz

Stadt Kassel, Naturkundemuseum (Ed.) (2011, continuously updated): Digitised specimen data at Naturkundemuseum im Ottoneum Kassel (NMOK)

E.C. Manning Park Collection

Lyman Entomological Museum

ArtDatabanken: Artdata

Crispin S. Guppy Observational Records

Royal British Columbia Museum Entomology Collection 
Chittaro Y. Swiss National Butterflies Databank. Centre Suisse de Cartographie de la Faune

Nicolaus Copernicus University of Torun: The Distribution Atlas of Butterflies in Poland

Crispin S. Guppy Collection

Lepidopterists' Society Season Summaries 1973-1997

Natural History Museum, University of Oslo: Norwegian Biodiversity Information Centre - Other datasets

GBIF-Sweden: Lepidoptera (Specimens NRM)

Finnish Museum of Natural History: Fieldjournal.org observation database

Jyvaskyla University Museum - The Section of Natural Sciences: Invertebrate collection of Jyvaskyla University Museum

Finnish Museum of Natural History: National Butterfly Survey of Finland

Alan Wormington Collection

Agriculture and Agri-Food Canada, St. John's, Newfoundland

Zoologische Staatssammlung Munchen/Staatliche Naturwissenschaftliche Sammlungen Bayerns: Zoologische Staatssammlung

Muenchen - International Barcode of Life (iBOL) - Barcode of Life Project Specimen Data

SysTax: SysTax - Zoological Collections

Butterflies and Skippers of Alberta Project

Inatura - Erlebnis Naturschau Dornbirn: inatura - Erlebnis Naturschau Dornbirn

GBIF-Sweden: Wetland Inventory (NV)

Royal Belgian Institute of Natural Sciences: RBINS collections

Sam Noble Oklahoma Museum of Natural History: Recent Invertebrates Specimens

Kenelm W. Philip lepidoptera collection

Natural History Museum, University of Oslo: Norwegian Lepidoptera working group

Donald F. Hooper Butterfly collection, Canada

Lepidoptera collection of Hannu Saarenmaa

University of Guelph, Department of Environmental Biology

Illinois Natural History Survey: Illinois Natural History Survey

Natural History Museum, University of Oslo: Helgeland Museum, Lepidoptera

Publications

(Bolotov, 2012; Gorbunov and Kosterin, 2007; Chernov and Tatarinov, 2006; Korb, 2014; Kozlov et al., 2006; Lukhtanov and

Lukhtanov, 1994b; Nekrutenko, 1990; Nekrutenko and Tshikolovets, 2005; Rubin and Yakovlev, 2013; Shokhrin, 2009; Tshikolovets,

2005; Tshikolovets, 2011; Tshikolovets and Nekrutenko, 2012; Tshikolovets et al., 2002; Tshikolovets et al., 2009a; Tshikolovets

et al., 2009b, Yakovlev, 2012)

\section{Appendix B. Supplementary material}

Supplementary data associated with this article can be found, in the online version, at http://dx.doi.org/10.1016/j.ympev.2015.06. 012.

\section{References}

Bentley, J., Verboom, G.A., Bergh, G.N., 2014. Erosive processes after tectonic uplift stimulate vicariant and adaptive speciation: evolution in an Afrotemperateendemic paper daisy genus. BMC Evol. Biol. 14, 27.

Bennett, G.M., O'Grady, P.M., 2012. Host-plants shape insect diversity: Phylogeny, origin, and species diversity of native Hawaiian leafhoppers (Cicadellidae: Nesophrosyne). Mol. Phylogenet. Evol. 65, 705-717.

Blomberg, S.P., Garland Jr., T., Ives, A.R., 2003. Testing for phylogenetic signal in comparative data: behavioral traits are more labile. Evolution 57, 717-745.

Bolotov, I.N., 2012. The fauna and ecology of butterflies (Lepidoptera, Rhopalocera) of the Kanin Peninsula and Kolguev Island. Entomol. Rev. 92, 296-304.

Bruno, W.J., Socci, N.D., Halpern, A.L., 2000. Weighted neighbor joining: a likelihood-based approach to distance-based phylogeny reconstruction. Mol. Biol. Evol. 17, 189-197.

Chamberlain, N.L. Hill, R.I. Kapan, D.D. Gilbert, L.E, Kronforst, M.R., 2009. Polymorphic butterfly reveals the missing link in ecological speciation. Science 326, 847-850.

Chernov, Y.I., Tatarinov, A.G., 2006. Butterflies (Lepidoptera, Rhopalocera) in the arctic fauna. Entomol. Rev 86, 760-786.

Chytry, M., Ermakov, N., Danihelka, J., Hajek, M., Hajkova, P., Horsak, M., Koci, M., Kubesova, S., Lustyk, P., Preislerova, Z., Pelankova, B., Valachovic, M., Zeleny, D., 2012. High species richness in hemiboreal forests of the northern Russian Altai, southern Siberia. J. Veg. Sci. 23, 605-616.

Condamine, F.L., Sperling, F.A.H., Wahlberg, N., Rasplus, J.Y., Kergoat, G.J., 2012. What causes latitudinal gradients in species diversity? Evolutionary processes and ecological constraints on swallowtail biodiversity. Ecol. Lett. 15, 267-277.

Database of animals of Altai-Sayan Ecoregion, <http://bioaltai-sayan.asu.ru> [online] [November 2014].

de Chaine, E.G., Martin, A.P., 2005. Historical biogeography of two alpine butterflies in the Rocky Mountains: Broad-scale concordance and local-scale discordance. J. Biogeogr. 32, 1943-1956.

De Grave, J., Buslov, M.M., Van den haute, P., 2007. Distant effects of India-Eurasia convergence and Mesozoic intracontinental deformation in Central Asia: constraints from apatite fission-track thermochronology. J. Asian Earth Sci. 29, $188-204$.

Dray, S., Dufour, A.B., Chessel, D., 2007. The ade4 package-II: two-table and K-table methods. R News. 7 (2), 47-52.

Drovetski, S.V., 2003. Plio-Pleistocene climatic oscillations, Holarctic biogeography and speciation in an avian subfamily. J. Biogeogr. 30, 1173-1181.

Drovetski, S.V., Semenov, G., Drovetskaya, S.S., Fadeev, I.V., Redkin, Y.A., Voelker, G., 2013. Geographic mode of speciation in a mountain specialist avian family endemic to the Palearctic. Ecol. Evol. 3, 1518-1528.

Drummond, A.J., Rambaut, A., 2007. BEAST: Bayesian evolutionary analysis by sampling trees. BMC Evol. Biol. 7, 214

Eidesen, P.B., Ehrich, D., Bakkestuen, V., Alsos, I.G., Gilg, O., Taberlet, P., Brochmann, C., 2013. Genetic roadmap of the Arctic: plant dispersal highways, traffic barriers and capitals of diversity. New Phytol. 200, 898-910.

Elias, S.A., Berman, A., Afimov, A., 2000. Late Pleistocene beetle faunas of Beringia: where east met west. J. Biogeogr. 27, 1349-1363.

Fjeldsa, J., Bowie, R.C.K. Rahbek, C. 2012. The role of mountain ranges in the diversification of birds. Annu. Rev. Ecol. Evol. Syst. 43, 249-265.

Fjeldsa, J., 2013. The global diversification of songbirds (Oscines) and the build-up of the Sino-Himalayan diversity hotspot. Chin. Birds 4, 132-143.

Gee, J.M., 2004. Gene flow across a climatic barrier between hybridizing avian species, California and Gambel's quail (Callipepla californica and C. gambelii). Evolution 58, 1108-1121.

Goloboff, P., Farris, J., Nixon, K., 2008. TNT, a free program for phylogenetic analysis. Cladistics 24, 774-786.

Gorbunov, P., Kosterin, O., 2007. The butterflies (Hesperioidea and Papilionoidea) of North Asia in Nature, vol. II. Rodina \& Fodio, Moscow.

Gorbunov, P.Y., 2001. The butterflies of Russia: classification, genitalia, keys for identification. (Lepidoptera: Hesperioidea and Papilionoidea). Thesis, Ekaterinburg.

Hall, A., 1999. BioEdit: a user-friendly biological sequence alignment editor and analysis program for Windows 95/98/NT. Nucleic Acids Symp. Ser. 41, 9598.

Hall, J.P.W., 2005. Montane speciation patterns in Ithomiola butterflies (Lepidoptera: Riodinidae): are they consistently moving up in the world? Proc. R. Soc. B 272, 2457-2466.

Hijmans, R.J., Cameron, S.E., Parra, J.L., Jones, P.G., Jarvis, A., 2005. Very high resolution interpolated climate surfaces for global land areas. Int. J. Climatol. 25, 1965-1978.

Hijmans, R.J., van Etten, J., Mattiuzzi, M., Summer, M., Greenberg, J.A., Lamigueiro, O.P., Bevan, A., Racine, E.B., Shortridge, A., 2014. Raster: Geographic Data Analysis and Modeling. <http://cran.at.r-project.org/web/packages/raster/ raster.pd>. 
Hope, A.G., Waltari, E. Dokuchaev, N.E. Abramov, S., Dupal, T. MacDonald, S.O. Henttonen, H., Cook, J.A., 2010. New perspectives on biotic diversification at high latitudes provided by the Eurasian least shrew and Alaskan tiny shrew (Soricidae). J. Mammal. 91, 1041-1057.

Hope, A.G., Takebayashi, N., Galbreath, K.E., Talbot, S.L., Cook, J.A., 2013. Temporal, spatial, and ecological dynamics of speciation among amphi-Beringian small mammals. J. Biogeogr. 40 (3), 415-429.

Imada, Y., Kawakita, A., Kato, M., 2011. Allopatric distribution and diversification without niche shift in a bryophyte-feeding basal moth lineage (Lepidoptera: Micropterigidae). Proc. R. Soc. B 278, 3026-3033.

Jiggins, C.D., 2008. Ecological speciation in mimetic butterflies. Bioscience 58, 541-548. Kadereit, J.W., Baldwin, B.G., 2012. Western Eurasian-western North American disjunct plant taxa: the dry-adapted ends of formerly widespread north temperate mesic lineages and examples of long-distance dispersal. Taxon 61, $3-17,15$.

Kamelin, R.V., 1998. Materials for a History of the Asian Flora (Altai Mountain Country). Altai State University, Barnaul.

Keller, I., Seehausen, O., 2012. Thermal adaptation and ecological speciation. Mol. Ecol. 21 (4), 782-799.

Kembel, S.W., Cowan, P.D., Helmus, M.R., Cornwell, W.K., Morlon, H., Ackerly, D.D. Blomberg, S.P., Webb, C.O., 2010. Picante: R tools for integrating phylogenies and ecology. Bioinformatics 26, 1463-1464.

Kim, S.S., Wan, X., Kim, M.J., Kim, I., 2013. Genetic relationships between Oeneis urda and 0 . mongolica (Nymphalidae: Lepidoptera). Entomol. Res, 43, 85-100.

Kleckova, I., Konvicka, M., Klecka, J., 2014. Thermoregulation and microhabitat use in mountain butterflies of the genus Erebia: importance of fine-scale habitat heterogeneity. J. Therm. Biol 41, 50-58.

Kodandaramaiah, U., Wahlberg, N., 2009. Phylogeny and biogeography of Coenonympha butterflies (Nymphalidae: Satyrinae) - patterns of colonization in the Holarctic. Syst. Entomol. 34, 315-323.

Korb, S.K., 2014. LepZhurnal annotated list of lepidoptera of nizhegorodskaya oblast. Lepidopterol. J. 3, 3-70 [In Russian].

Kozlov, M.V., Kullberg, J., Dubatolov, V.V., 2006. Lepidoptera of the Taymyr peninsula, northwestern Siberia. Entomol. Fennica 17, 136-152.

Layberry, R.A., Hall, P.W., Lafontaine, J.D., 1998. The Butterflies of Canada. University of Toronto Press, Toronto.

Leneveu, J., Chichvarkhin, A., Wahlberg, N., 2009. Varying rates of diversification in the genus Melitaea (Lepidoptera: Nymphalidae) during the past 20 million years. Biol. J. Linn. Soc. 97, 346-361.

Lukhtanov, V., Lukhtanov, A., 1994. Die Tagfalter Nordwestasiens (Lepidoptera, Diurna). Herbipoliana. Buchreihezur zur lepidopterologie. Band 3. Herausgeber Dr. Ulf Eitschberger, Marktleuthen.

Lukhtanov, V., Lukhtanov, A., 1994. Die Tagfalter Nordwestasiens (Lepidoptera, Diurna). Herbipoliana Band 3. Dr. Ulf Eitschberger, Marktleuthen.

Matos-Maravi, P.F., Peña, C., Willmott, K.R., Freitas, A.V.L., Wahlberg, N., 2013 Systematics and evolutionary history of butterflies in the "Taygetis clade" (Nymphalidae: Satyrinae: Euptychiina): towards a better understanding of Neotropical biogeography. Mol. Phylogenet. Evol. 66, 54-68.

Miller, M.A., Pfeiffer, W., Schwartz, T., 2010. Creating the CIPRES Science Gateway for inference of large phylogenetic trees. In: Proceedings of the Gateway Computing Environments Workshop (GCE), 14 Nov. 2010, New Orleans, LA, pp. 1-8.

Mullen, S.P., 2006. Wing pattern evolution and the origins of mimicry among North American admiral butterflies (Nymphalidae: Limenitis). Mol. Phylogenet. Evol. 39, 747-758.

Muller, C.J., Beharegaray, L.B., 2010. Palaeo island-affinities revisited biogeography and systematics of the Indo-Pacific genus Cethosia Fabricius (Lepidoptera: Nymphalidae). Mol. Phylogenet. Evol. 57, 314-326.

Nekrutenko, Y.P., 1990. Dnevnye babochki Kavkaza. Naukova Dumka, Kiev.

Nekrutenko, Y.P., Tshikolovets, V.V., 2005. Butterflies of Ukraine. Raevskiy, Kiyv (in Ukrainian).

Opler, P.A., Wright, A.B., 1999. A Field Guide to Western Butterflies (Peterson Field Guides). Houghton Mifflin Co., Boston.

Päckert, M., Martens, J., Sun, Y.H., Severinghaus, L.L., Nazarenko, A.A., Ting, J., Töpfer T., Tietze, D.T., 2012. Horizontal and elevational phylogeographic patterns of Himalayan and Southeast Asian forest passerines (Aves: Passeriformes). J. Biogeogr. 39, 556-573.

Paradis, E., Claude, J., Strimmer, K., 2004. APE: analyses of phylogenetics and evolution in R language. Bioinformatics 20, 289-290.

Pelham, unpublished. Systematic Catalogue of the Genus Oeneis.

Peña, C., Nylin, S., Wahlberg, N., 2011. The radiation of Satyrini butterflies (Nymphalidae: Satyrinae): a challenge for phylogenetic methods. Zool. J. Linn. Soc-Lond. 161, 64-87.

Posada, D., Crandall, K.A., 2001. Selecting the best-fit model of nucleotide substitution. Syst. Biol. 50, 580-601.

Rambaut, A., 2009. FigTree, ver. 1.3.1. [Online]. Available: FigTree v 1.3.1 <http:// tree.bio.ed.ac.uk/software/figtree/> (February 2009).

Rambaut, A., Drummond, A.J., 2003-2009. Tracer: MCMC Trace Analysis Tool, v1.5.0. <http://tree.bio.ed.ac.uk/software/tracer/> (February 2009).

R Core Team, 2012. R: A Language and Environment for Statistical Computing. R Foundation for Statistical Computing. Vienna, Austria. <http://www.R-project. org/>.

Revell, L.J., 2012. Phytools: an R package for phylogenetic comparative biology (and other things). Methods Ecol. Evol. 3, 217-223.

Rieseberg, L.H., Whitton, J., Gardner, K., 1999. Hybrid zones and the genetic architecture of a barrier to gene flow between two sunflower species. Genetics $152,713-727$.
Ronquist, F., Huelsenbeck, J.P., 2003. MRBAYES 3: Bayesian phylogenetic inference under mixed models. Bioinformatics 19, 1572-1574.

Rubin, N.I., Yakovlev, R.V., 2013. Checklist of the butterflies (Papilionoidea) of the Saur Mountains and adjacent territories (Kazakhstan), including systematic notes about the Erebia callias group. Nota Lepidopterol. 36, 137-170.

Rundell, R.J., Price, T.D., 2009. Adaptive radiation, nonadaptive radiation, ecological speciation and nonecological speciation. Trends Ecol. Evol. 24, $394-$ 399.

Sanmartin, I., Enghoff, H., Ronquist, F., 2001. Patterns of animal dispersal, vicariance and diversification in the Holarctic. Biol. J. Linn. Soc. 73, 345-390.

Schmitt, T., Hewitt, G.M., 2004. Molecular biogeography of the arctic-alpine disjunct burnet moth species Zygaena exulans (Zygaenidae, Lepidoptera) in the Pyrenees and Alps. J. Biogeogr. 31, 885-893.

Schmitt, T Haubrich, K, 2008. The genetic structure of the mountain forest butterfly Erebia euryale unravels the late Pleistocene and postglacial history of the mountain coniferous forest biome in Europe. Mol. Ecol. 17, 2194-2207.

Schmitt, T., Hewitt, G.M., Muller, P., 2006. Disjunct distributions during glacial and interglacial periods in mountain butterflies: Erebia epiphron as an example. J. Evol. Biol. 19, 108-113.

Schweiger, O., Settele, J., Kudrna, O., Klotz, S., Kühn, I., 2008. Climate change can cause spatial mismatch of trophically interacting species. Ecology 89, 3472-3479.

Shokhrin, V.P., 2009. Diurnal - Butterflies. In: Storozhenko, S.Yu. (Ed.), Insects of Lazovsky Nature Reserve. Dalnauka, Vladivostok, pp. 315-326.

Simonsen, T.J., Wahlberg, N., Warren, A.D., Sperling, F.A.H., 2010. The evolutionary history of Boloria (Lepidoptera: Nymphalidae): phylogeny, zoogeography and larval-foodplant relationships. Syst. Biodivers. 8, 513-529.

Swensson, E.I., 2012. Non-ecological speciation, niche conservatism and thermal adaptation: how are they connected? Org. Divers. Evol. 12, 229-240.

Tiffney, B.H., 1985. The Eocene North Atlantic land bridge: its importance in Tertiary and modern phytogeography of the Northern Hemisphere. J. Arnold Arboretum $66,243-273$.

Todisco, V., Gratton, P., Wheat, C., Zakharov, E., Sbordoni, V., Sperling, F., 2012. Mitochondrial phylogeography of the Holarctic Parnassius phoebus complex supports a recent refugial model for alpine butterflies. J. Biogeogr. 39, 1058 1072.

Tshikolovets, V.V., 2005. The Butterflies of Kyrgyzstan. Vadim V. Tshikolovets, Brno. shikolovets, V.V., 2011. Butterflies of Europe \& the Mediterranean Area. Tshikolovets Publications, Pardubice.

Tshikolovets, V.V., Bidzilya, A., Golovoskin, M.I., 2002. Butterflies of Transbaikal Siberia. Konvoj, Brno.

Tshikolovets, V.V., Nekrutenko, Y., 2012. The Butterflies of Caucasus and Transcaucasia (Armenia, Azerbaijan, Georgia and Russian Federation). Tshikolovets Publications, Pardubice.

Tshikolovets, V.V., Yakovlev, R.V., Kosterin, O.E., 2009a. The butterflies of Atai, Sayan and Tuva (South Siberia). Vadim V. Tshikolovets, Kiev.

Tshikolovets, V.V., Yakovlev, R.V., Balint, Z., 2009b. The Butterflies of Mongolia. Vadim V. Tshikolovets, Kiev.

Tuzov, V.K., Bogdanov, P.V., Devyatkin, A.L., Kaabak, L.V., Korolev, V.A., Murzin, V.S. Samodurov, G.D., Tarasov, E.A., 1997. Guide to the butterflies of Russia and adjacent territories (Lepidoptera, Rhopalocera). In: Tuzov, V.K. (Ed.). Volume 1: Hesperiidae, Papilionidae, Pieridae, Satyridae. Pensoft Series Faunistica No 7, Sofia-Moscow.

van Swaay, C., Warren, M., Loïs, G., 2006. Biotope use and trends of European butterflies. J. Insect Conserv. 10, 189-209.

Valdiya, K.S., 2002. Emergence and evolution of Himalaya: reconstructing history in the light of recent studies. Prog. Phys. Geog. 26, 360-399.

Vila, R., Bell, C.D., Macniven, R., Goldman-Huertas, B., Ree, R.H., Marshall, C.R., Balint, Z., Johnson, K., Benyamini, D., Pierce, N.E., 2011. Phylogeny and palaeoecology of Polyommatus blue butterflies show Beringia was a climate-regulated gateway to the New World. Proc. Roy. Soc. B 278, 2737-2744.

Wahlberg, N., Wheat, C.W., 2008. Genomic outposts serve the phylogenomic pioneers: designing novel nuclear markers for genomic DNA extractions of Lepidoptera. Syst. Biol. 57, 231-242.

Warren, A.D., Austin, G.T., Llorente, J.E., Luis, A.M., Vargas, I.F., 2008. A new species of Neominois from northeastern Mexico (Lepidoptera: Nymphalidae: Satyrinae) Zootaxa 1896, 31-44.

Weber, W.A., 2003. The Middle Asian element in the southern Rocky Mountain flora of the western United States: a critical biogeographic review. J. Biogeogr. 30, 649-685.

Willmott, K.R., Hall, J.P.W., Lamas, G., 2001. Systematics of Hypanartia (Lepidoptera: Nymphalidae: Nymphalinae), with a test for geographical speciation mechanisms in the Andes. Syst. Entomol. 26, 369-399.

Xu, T., Abbott, R.J., Milne, R.I., Mao, K., Du, F.K., Wu, G., Ciren, Z., Miehe, G., Liu, J., 2010. Phylogeography and allopatric divergence of cypress species (Cupressus L.) in the Qinghai-Tibetan Plateau and adjacent regions. BMC Evol. Biol. 10, 194

Yakovlev, R.V., 2012. Checklist of Butterflies (Papilionoidea) of the Mongolian Altai Mountains, including descriptions of new taxa. Nota Lepidopterol. 35, 51-96.

Yannic, G., Pellissier, L., Ortego, J., Lecomte, N., Couturier, S., Cuyler, C., Dussault, C., Hundertmark, K.J., Irvine, R.J., Jenkins, D.A., Kolpashikov, L., Mager, K., Musiani, M., Parker, K.L., Rřed, K.H., Sipko, T., Tórisson, S.G., Weckworth, B.V., Guisan, A., Bernatchez, L., Côté, S.D., 2014. Genetic diversity in caribou linked to past and future climate change. Nature Clim. Change 4, 132-137.

Yu, Y., Harris, A.J., He, X.-J., 2013. RASP (Reconstruct Ancestral State in Phylogenies) 2.1 Beta. <http://mnh.scu.edu.cn/soft/blog/RASP>.

Zachos, J., Pagani, M., Sloan, L., Thomas, E., Billups, K., 2001. Trends, rhythms, and aberrations in global climate 65 Ma to present. Science 292, 686-693. 